\title{
Pregnant During the Study
}

National Cancer Institute

\section{Source}

National Cancer Institute. Pregnant During the Study. NCI Thesaurus. Code C106561.

An indicator as to whether the female subject is pregnant during the study period. 